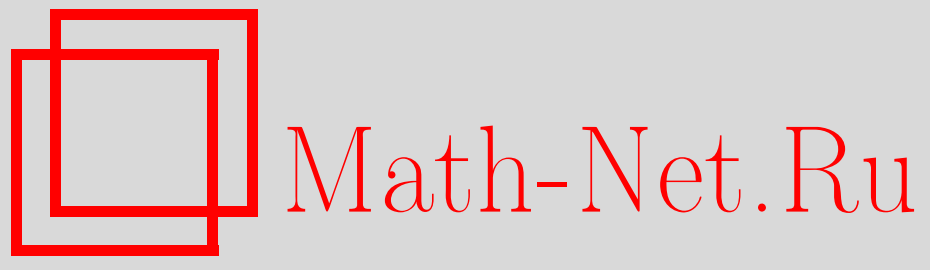

Поздравления с юбилеем, Теория вероятн. и ее примен., 2022, том 67, выпуск 1, 176

DOI: https://doi.org/10.4213/tvp5547

Использование Общероссийского математического портала Math-Net.Ru подразумевает, что вы прочитали и согласны с пользовательским соглашением http://www.mathnet.ru/rus/agreement

Параметры загрузки:

IP : 54.89 .56 .158

26 апреля 2023 г., 12:39:41

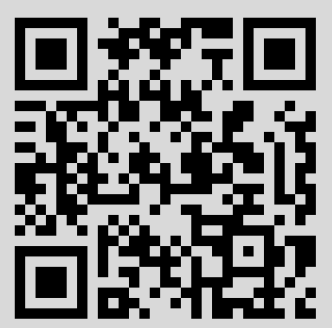




\section{ПОЗДРАВЛЕНИЯ С ЮБИЛЕЕМ}

30 декабря 2021 года исполнилось 75 лет члену редколлегии журнала “Теория вероятностей и ее применения", академику Академии криптографии Российской Федерации

\section{Андрею Михайловичу Зубкову}

1 января 2022 года исполнилось 70 лет заместителю главного редактора журнала

"Теория вероятностей и ее применения", члену-корреспонденту Академии криптографии Российской Федерации

\section{Владимиру Алексеевичу Ватутину}

Редакционная коллегия журнала "Теория вероятностей и ее применения" сердечно поздравляет юбиляров и желает им здоровья и дальнейших творческих успехов. 